\title{
Potensi Aktivitas Antioksidan Ekstrak Etanol Dan Fraksi $n$ - Heksan Buah Jeruk Pamelo (Citrus maxima (Burm) Merr) Asal Kabupaten Pangkep
}

\author{
Masdiana Tahir ${ }^{1 *}$, Asriani Suhaenah ${ }^{1}$, Yulinda Rahim ${ }^{1}$ \\ ${ }^{1}$ Fakultas Farmasi Universitas Muslim Indonesia Makassar
}

\begin{tabular}{|c|c|}
\hline Article info & Abstract \\
\hline History & Pomelo citrus (Citrus maxima (Burm) Merr) is a fruit plant that has the \\
\hline Submission: 03-04-2019 & potential to be developed for health. Pomelo fruit contains lycopene, \\
\hline Review: $23-12-2019$ & flavonoids and vitamin $C$ which can provide antioxidant activity. The \\
\hline Accepted: 13-07-2020 & purpose of this study was to determine the potential antioxidant activity of \\
\hline $\begin{array}{l}\text { *Email: } \\
\text { masdiana.tahir@umi.ac.id }\end{array}$ & $\begin{array}{l}\text { ethanol extract and fraction of n-hexane of pomelo citrus using quercetin as } \\
\text { a comparison. Extraction of Pomelo citrus fruit using the maceration } \\
\text { method with liquid-liquid fractionation using water and n-hexane }(1: 3 \mathrm{v} /\end{array}$ \\
\hline DOI: $10.33096 /$ jffi.v7i2.488 & $\begin{array}{l}\text { v). Testing of antioxidant activity using the DPPH (1,1-Diphenyl-2- } \\
\text { picrylhidrazil) method is based on the ability of the sample to capture DPPH }\end{array}$ \\
\hline Keywords: & free radicals which are characterized by purple to yellow discoloration and \\
\hline $\begin{array}{l}\text { Antioxidants; Ethanol Extract; } \\
\text { n-Hexane Fraction; Pamelo }\end{array}$ & $\begin{array}{l}\text { a decrease in the absorbance value of DPPH which has reacted with } \\
\text { samples in certain concentrations. Absorbance measurements using a UV- }\end{array}$ \\
\hline $\begin{array}{l}\text { citrus (Citrus maxima (Burm) } \\
\text { Merr }\end{array}$ & Vis spectrophotometer at a wavelength of $514,942 \mathrm{~nm}$. The results showed \\
\hline & $\begin{array}{l}\text { that the } I_{50} \text { value of quercetin was } 6.55 \mu \mathrm{g} / \mathrm{mL} \text { which was a strong } \\
\text { antioxidant, while the IC } C_{50} \text { value of the ethanol extract of pomelo citrus fruit } \\
\text { was } 2882.26 \mu \mathrm{g} / \mathrm{mL} \text { and } I C_{50} \text { value of the } n \text {-hexane fraction of pomelo } \\
\text { orange was } 3668,44 \mu \mathrm{g} / \mathrm{mL} \text { which is a weak antioxidant category. }\end{array}$ \\
\hline
\end{tabular}

\section{Pendahuluan}

Jeruk pamelo merupakan tanaman buah yang potensial untuk dikembangkan di Indonesia dan salah satu sentra produksi jeruk besar atau jeruk pamelo di Sulawesi Selatan adalah Kabupaten Pangkep. Jeruk pamelo, jeruk besar, atau yang lebih dikenal dengan sebutan jeruk Bali (bahasa Inggris: pomelo, latin: (Citrus maxima (Burm) Merr) merupakan jeruk penghasil buah terbesar. Nama "Pamelo" sekarang disarankan oleh Departemen Pertanian karena jeruk ini tidak ada kaitannya dengan Bali. Jeruk ini termasuk jenis jeruk yang mampu beradaptasi dengan baik pada daerah kering dan relatif tahan terhadap penyakit (Dewi \& Mustika, 2014).

Buah jeruk pamelo mengandung likopen, flavonoid, provitamin A, vitamin C, pektin, vitamin B1 dan B2, asam folat, gula, protein, lemak karbohidrat, retinol, kalsium dan fosfor (Junaidi,2011). Berdasarkan kandungan senyawa kimianya, maka buah jeruk pamelo merupakan salah satu bahan alam yang potensial untuk dikembangkan bagi kesehatan misalnya sebagai antioksidan.

Antioksidan adalah senyawa yang mampu menangkal atau meredam radikal bebas dalam tubuh. Antioksidan bekerja dengan cara mendonorkan satu elektronnya kepada senyawa yang bersifat oksidan sehinggan aktivitas senyawa oksidan tersebut bias dihambat (Winarsi, 2007).
Tubuh manusia tidak mempunyai cadangan antioksidan dalam jumlah yang berlebih, sehingga jika terjadi paparan radikal berlebih maka tubuh membutuhkan antioksidan eksogen. Adanya kekhawatiran akan kemungkinan efek samping yang belum diketahui dari antioksidan sintetik menyebabkan antioksidan alami menjadi alternatif yang sangat dibutuhkan (Rohdiana, 2001 \& Sunarni, 2005). Antioksidan dapat berupa antioksidan sintetik maupun antioksidan alami. Antioksidan alami dapat berasal dari tumbuh-tumbuhan, buahBuahan, sayur-sayuran dan rempah-rempahan. Senyawa kimia yang termasuk kelompok antioksidan yang ditemukan pada tanaman, antara lain dari golongan polifenol, vitamin $\mathrm{C}$, vitamin $\mathrm{E}$, karoten dan flavanoid (Hernani, 2005).

Beberapa penelitian tentang jeruk pamelo asal Kab. Pangkep telah dilakukan diantaranya analisis kandungan vitamin $\mathrm{C}$ pada daging buah jeruk pamelo diperoleh kadar untuk varietas jeruk pamelo daging merah $0,721 \mathrm{mg} / \mathrm{g}$ dan daging putih 0,107 $\mathrm{mg} / \mathrm{g}$ (Tahir,M dkk, 2018). Dan telah dilakukan analisis kadar likopen yang merupakan golongan senyawa karoten pada buah jeruk pamelo di peroleh kadar likopen jeruk pamelo daging merah $32,444 \mathrm{mg} / \mathrm{kg}$ sampel segar dan daging putih 2,801 $\mathrm{mg} / \mathrm{kg}$ sampel segar (Tahir,M.dkk, 2018). Serta uji aktivitas perlindungan sinar UV sari buah jeruk pamelo berdasarkan nilai SPF diperoleh nilai SPF untuk varietas daging merah 36,70 dan daging putih

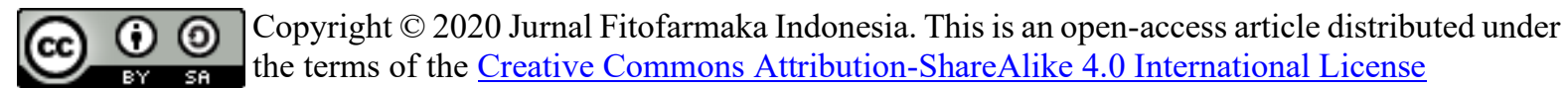


35,50 yang merupakan kategori SPF tinggi (Tahir, M.\& Melisa, 2018).

Berdasarkan kajian tersebut diatas, maka dilakukan penelitian untuk menguji potensi aktivitas antioksidan ekstrak buah jeruk pamelo (Citrus maxima (Burm) Merr) asal Kab.Pangkep dengan metode peredaman radiakal bebas yaitu menggunakan senyawa DPPH (1,1-Diphenyl-2picrylhidrazil).

\section{Metode Penelitian}

\section{II.1 Alat dan Bahan}

Alat yang digunakan adalah seperangkat alat maserasi, alat-alat gelas, mikropipet, timbangan analitik (And dan OHAUS), Rotary Vacuum Evaporator (Rotavapor), alat vakum, seperangkat alat penyaring Buchner dan spektrofotometer UVVis (Thermo Scientific Evolution 201).

Bahan-bahan yang digunakan adalah pelarut teknis n-heksan dan etanol, metanol P.a., aquades, kuersetin sebagai standar baku, senyawa radikal DPPH (1,1-difenil-2-pikrilhidrakzil) dan sampel buah jeruk pamelo (Citrus maxima (Burm) Merr) varietas daging merah.

\section{II.2 Pengolahan Sampel}

Daging buah jeruk pamelo (Citrus maxima (Burm) Merr) varietas daging merah yang akan dianalisis dibersihkan terlebih dahulu, kulitnya dikupas dan butiran-butiran daging buah dipisahkan dari sekat-sekatnya. Kemudian daging buah jeruk pamelo (Citrus maxima (Burm) Merr) dihaluskan dengan menggunakan blender (dengan penambahan sedikit pelarut) (Ervina syahfitri, 2012).

\section{II.3 Pembuatan Ekstrak Etanol dan Fraksi $n$ - Heksan \\ 1. Pembuatan Ekstrak Etanol Buah Jeruk Pamelo \\ Buah jeruk pamelo (Citrus maxima (Burm.)} Merr) yang telah dihaluskan, dimasukkan ke dalam erlenmeyer $500 \mathrm{~mL}$ dan ditambahkan $300 \mathrm{~mL}$ etanol $96 \%$ sampai seluruh sampel terendam. Pelarut dilebihkan setinggi kurang lebih $2 \mathrm{~cm}$ di atas permukaan sampel, ditutup dan dibiarkan selama 1x24 jam dan dilakukan proses maserasi. Maserat disaring dengan menggunakan kertas saring. Filtrat diperoleh melalui penyaringan dengan corong Buchner dengan bantuan pompa vakum. Kemudian ampas dimaserasi kembali dengan etanol selama 1x24 jam, sehingga filtrat hampir tidak berwarna. Filtrat dipekatkan dengan menggunakan rotavapor hingga diperoleh ekstrak etanol kental buah jeruk pamelo.

\section{Pembuatan Fraksi n-Heksan Buah Jeruk Pamelo}

Ekstrak etanol kental buah jeruk pamelo ditambahkan $10 \mathrm{~mL}$ air hangat dan diekstraksi caircair menggunakan n-heksan dengan perbandingan larutan air : n-heksan (1:3 v/v) sehingga didapatkan fraksi n-heksan. Setelah dipisahkan, pelarut dari fraksi n-heksan diuapkan menggunakan rotavapor hingga diperoleh fraksi n-heksan kental ekstrak etanol buah jeruk pamelo (Mikhael \& Soegihardjo, 2013).

\section{II.4 Penentuan Aktivitas Antioksidan}

\section{Penentuan Panjang Gelombang Maksimum} DPPH

Penentuan panjang gelombang maksimum dengan cara mengukur 4,0 mL larutan DPPH 50 ppm pada spektrofotometer UV-Vis dengan range panjang gelombang 400-600 $\mathrm{nm}$ dan diperoleh panjang gelombang maksimumnya adalah 514,942 nm.

\section{Penentuan Aktivitas Antioksidan Baku Pembanding Kuersetin}

Sebanyak 2 mL larutan DPPH ditambahkan dengan masing-masing $1 \mathrm{~mL}$ larutan kuersetin konsentrasi 2, 4, 6, 8, dan 10 ppm dari larutan stok $100 \mathrm{ppm}$. Selanjutnya larutan tersebut dikocok kuat menggunakan vortex, diinkubasi selama 30 menit, lalu diukur absorbansinya menggunakan spektrofometer UV-Vis pada panjang gelombang $514,942 \mathrm{~nm}$ (Navitri \& Monica, 2012).

\section{Penentuan Aktivitas Antioksidan Ekstrak Etanol dan Fraksi n-Heksan Buah Jeruk Pamelo}

Ekstrak etanol dengan konsentrasi 1000, 2000, 3000, 4000 dan 5000 ppm, dan fraksi nheksan dengan konsentrasi 1000, 2000, 3000, 4000 dan 5000 ppm dari larutan stok 5000 ppm. Sebanyak $1 \mathrm{~mL}$ dari masing-masing larutan ekstrak tersebut ditambahkan $2 \mathrm{~mL}$ larutan DPPH (1,1 difenil-2pikrilhidrokzil) $\quad 0,4 \mathrm{mM}$. Selanjutnya larutan tersebut dikocok menggunakan vortex, diinkubasi selama 30 menit, lalu diukur absorbansinya menggunakan spektrofometer UV-Vis pada panjang gelombang 514,942 nm. Perlakuan yang sama juga dilakukan terhadap blanko yang berisi etanol.

\section{II.5 Analisis Data}

Besarnya presentase pengikat radikal bebas $(\%$ inhibisi) dihitung dengan rumus:

$\%$ Inhibisi $=\frac{(\text { Abs standar- }(\text { Abs sampel-Abs blanko })}{\text { Abs standar }} \times 100 \%$

Nilai $\mathrm{IC}_{50}$ dihitung dengan menggunakan persamaan regresi linear konsentrasi sampel sebagai sumbu $\mathrm{x}$ dan $\%$ inhibisi sebagai sumbu $\mathrm{y}$. Dari persamaan: $y=a+b x$, dapat dihitung nilai $\mathrm{IC}_{50}$ dengan menggunakan rumus:

$$
\mathrm{IC}_{50}=\frac{(50-\mathrm{b})}{\mathrm{a}}
$$

\section{Hasil Dan Pembahasan}

Hasil ekstraksi buah jeruk pamelo (Citrus maxima (Burm.) Merr) dengan metode maserasi menggunakan pelarut etanol $96 \%$ diperoleh persen rendamen sebesar $10,85 \%$ dari $150 \mathrm{~g}$ sampel segar buah jeruk pamelo dan hasil fraksinasi ekstrak 
etanol buah jeruk pamelo dengan metode ekstraksi cair-cair menggunakan corong pisah diperoleh persen rendamen fraksi n-heksan sebesar $1,18 \%$ dari $10 \mathrm{~g}$ ekstrak etanol.

Untuk uji aktivitas antioksidan digunakan metode peredaman radikal bebas DPPH (1,1diphenyl-2-picrylhydrazyl). Aktivitas antioksidan diukur berdasarkan kemampuan untuk menangkap radikal bebas DPPH. Keberadaan antioksidan akan menetralisasi radikal DPPH dengan menyumbangkan elektron kepada DPPH, menghasilkan perubahan warna dari ungu menjadi kuning. Penghilangan warna akan sebanding dengan jumlah elektron yang diambil oleh DPPH sehingga dapat diukur secara spektrofotometri (Prakash, 2001). Pengukuran absorbansi dilakukan pada panjang gelombang serapan maksimal, yaitu panjang gelombang yang mempunyai absorbansi maksimal. Secara teoritis, panjang gelombang maksimum DPPH dalam etanol diukur pada panjang gelombang 400-600 nm. Hasil pengukuran panjang gelombang maksimum DPPH 50 PPM diperoleh panjang gelombang maksimum 514,942 nm dengan nilai absorbansi sebesar 0,965.

Persen penangkapan radikal bebas DPPH digunakan untuk membandingkan aktivitas peredaman radikal bebas DPPH oleh kuersetin dengan ekstrak etanol dan fraksi n-heksan buah jeruk pamelo (Citrus maxima (Burm.) Merr). Sedangkan $\mathrm{IC}_{50}$ merupakan konsentrasi efektif senyawa uji dalam menghasilkan aktivitas peredaman radikal bebas DPPH sebesar $50 \%$.
Variasi seri konsentrasi dibuat untuk memperoleh persamaan regresi linier sehingga dapat ditentukan nilai $\mathrm{IC}_{50}$, dimana nilai $\mathrm{IC}_{50}$ dihitung menggunakan persamaan garis regresi linier antara konsentrasi senyawa uji sebagai sumbu $\mathrm{x}$ dan persen inhibisi sebagai sumbu y (Winarsi, 2007).

Pada penelitian ini digunakan Kuersetin sebagai pembanding karena kuersetin merupakan senyawa golongan flavanoid jenis flavonol dan flavon, dimana senyawa flavon memiliki sifat antioksidan. Pengujian nilai aktivitas antioksidan kuersetin sebagai pembanding dilakukan dengan membuat larutan standar kuersetin dalam 5 seri konsentrasi yaitu konsentrasi 2; 4; 6; 8; 10 ppm. Masing-masing konsentrasi dipipet $1 \mathrm{~mL}$ dan ditambahkan $2 \mathrm{~mL}$ DPPH 50 ppm, diinkubasi selama 30 menit. Setelah itu diukur absorbansinya pada panjang gelombang maksimum 514,942 nm. Absorbansi yang diperoleh digunakan untuk menghitung \% inhibisi radikal bebas dan dibuat kurva penghambatan standar kuersetin, plot antara $\%$ inhibisi dan konsentrasi dan diperoleh persamaan regresi linear $y=6,4767 x+7,5646$ dengan nilai koefisien korelasi $\mathrm{R}=0,999$ yang memenuhi syarat analisis (Gambar 1). Dari nilai persamaan regresi linear tersebut dihitung nilai aktivitas antioksidannya dalam nilai $\mathrm{IC}_{50}$ dimana $\mathrm{y}=50$ (penghambatan $50 \%$ oksidasi) dan $\mathrm{x}$ adalah nilai $\mathrm{IC}_{50}$. Dari hasil perhitungan diperoleh $\mathrm{IC}_{50}$ standar kuersetin adalah $6,55 \mu \mathrm{g} / \mathrm{mL}$ yang dapat dilihat pada Tabel 1.

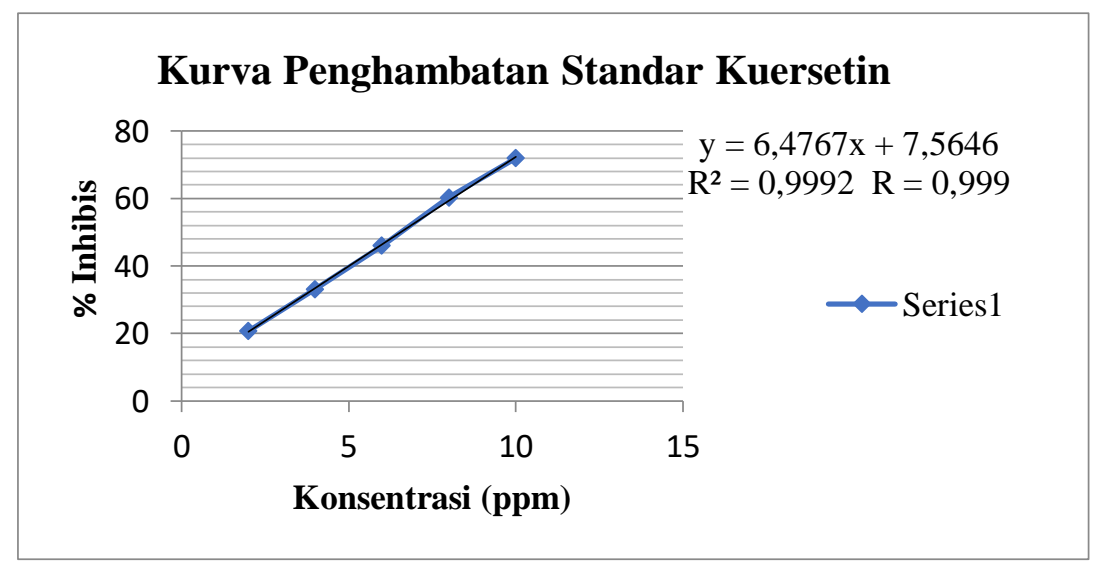

Gambar 1. Pengaruh konsentrasi terhadap \% inhibisi larutan standar kuersetin (pembanding)

Tabel 1. Hasil pengukuran absorbansi, persentasi peredaman DPPH dan nilai $\mathrm{IC}_{50}$ dari kuersetin (pembanding)

\begin{tabular}{cccc}
\hline $\begin{array}{c}\text { Konsentrasi } \\
(\mathbf{p p m})\end{array}$ & Absorbansi & \% Inhibisi & IC $_{\mathbf{5 0}}(\boldsymbol{\mu g} \mathbf{m} \mathbf{m L})$ \\
\hline 2 & 0,765 & 20,725 & \\
4 & 0,645 & 33,161 & \\
6 & 0,521 & 46,010 & 6,55 \\
8 & 0,383 & 60,311 & \\
10 & 0,271 & 71,917 & \\
\hline
\end{tabular}


Pengujian nilai aktivitas antioksidan ekstrak etanol buah jeruk pamelo (Citrus maxima (Burm.) Merr) dengan metode peredaman radikal bebsa DPPH. Langkah pertama, pembuatan larutan stok ekstrak etanol, kemudian dibuat dalam 5 seri konsentrasi yaitu 1000; 2000; 3000; 4000; dan 5000 ppm. Masing-masing konsentrasi dipipet $1 \mathrm{~mL}$ dan ditambahkan $2 \mathrm{~mL}$ DPPH $50 \mathrm{ppm}$, diinkubasi selama 30 menit. Setelah itu diukur absorbannya pada panjang gelombang maksimum 514,942 nm. Absorbansi yang diperoleh digunakan untuk menghitung \% inhibisi radikal bebas DPPH dan dibuat kurva penghambatan ekstrak etanol buah jeruk pamelo diperoleh persamaan regresi $\mathrm{y}=$ $0,0097 x+22,042$ dengan nilai koefisien korelasi $\mathrm{R}$ $=0,998$ yang memenuhi syarat analisis. Dari persamaan regresi linear diperoleh $\mathrm{IC}_{50}$ ekstrak etanol buah jeruk pamelo sebesar 2882,26 $\mu \mathrm{g} / \mathrm{mL}$ $\mu \mathrm{g} / \mathrm{mL}$ yang dapat dilihat pada Tabel 2 dan hasil pengukuran fraksi n-heksan diperoleh persamaan regresi $y=0,009 x+16,984$ dengan nilai koefisien korelasi $\mathrm{R}=0,996$ dan diperoleh $\mathrm{IC}_{50}$ fraksi $\mathrm{n}$ heksan ekstrak etanol buah jeruk pamelo sebesar 3668,44 $\mu \mathrm{g} / \mathrm{mL}$ yang dapat dilihat pada Tabel 3.

Tabel 2. Hasil pengukuran absorbansi, persentasi peredaman DPPH dan nilai $\mathrm{IC}_{50}$ dari ekstrak etanol buah jeruk pamelo (Citrus maxima (Burm.) Merr)

\begin{tabular}{cccc}
\hline $\begin{array}{c}\text { Konsentrasi } \\
(\mathbf{p p m})\end{array}$ & Absorbansi & \% Inhibisi & IC $_{\mathbf{5 0}}(\boldsymbol{\mu g} \mathbf{g} \mathbf{m L})$ \\
\hline 1000 & 0,664 & 31,192 & \\
2000 & 0,560 & 41,969 & \\
3000 & 0,462 & 52,124 & 2882,26 \\
4000 & 0,385 & 60,104 & \\
5000 & 0,282 & 70,777 & \\
\hline
\end{tabular}

Tabel 3. Hasil pengukuran absorbansi, persentasi peredaman DPPH dan nilai $\mathrm{IC}_{50}$ dari fraksi n-heksan buah jeruk pamelo (Citrus maxima (Burm.) Merr)

\begin{tabular}{cccc}
\hline $\begin{array}{c}\text { Konsentrasi } \\
(\mathbf{p p m})\end{array}$ & Absorbansi & \% Inhibisi & IC $_{\mathbf{5 0}}(\boldsymbol{\mu g} \mathbf{g} \mathbf{m L})$ \\
\hline 1000 & 0,717 & 25,699 & \\
2000 & 0,627 & 35,026 & \\
3000 & 0,541 & 43,938 & 3668,44 \\
4000 & 0,434 & 55,026 & \\
5000 & 0,377 & 60,933 & \\
\hline
\end{tabular}

Hasil penelitian menunjukkan bahwa nilai $\mathrm{IC}_{50}$ dari kuersetin sebesar $6,55 \mu \mathrm{g} / \mathrm{mL}$, sedangkan nilai $\mathrm{IC}_{50}$ dari ekstrak etanol buah jeruk pamelo sebesar 2882,26 $\mu \mathrm{g} / \mathrm{mL}$ dan nilai $\mathrm{IC}_{50}$ dari fraksi nheksan buah jeruk pamelo sebesar 3668,44 $\mu \mathrm{g} / \mathrm{mL}$. Menurut pembagian kategori antioksidan Blois (Yanhouy, 2011) suatu bahan alam (raw material) yang memiliki $\mathrm{IC}_{50}$ kurang dari $50 \mu \mathrm{g} / \mathrm{mL}$ dapat dikategorikan sebagai antioksidan yang sangat kuat, 50-100 $\mu \mathrm{g} / \mathrm{mL}$ sebagai antioksidan sedang dan jika lebih dari $159 \mu \mathrm{g} / \mathrm{mL}$ dikategorikan sebagai antioksidan lemah. Sehingga kuersetin berpotensi sebagai antioksidan sangat kuat, sedangkan sampel ekstrak etanol dan fraksi n-heksan buah jeruk pamelo berpotensi sebagai antioksidan lemah.

\section{Kesimpulan}

Berdasarkan hasil penelitian yang telah dilakukan, maka dapat disimpulkan bahwa ekstrak etanol dan fraksi n-heksan buah jeruk pamelo (Citrus maxima (Burm.) Merr) memiliki aktivitas sebagai antioksidan dengan nilai aktivitas antioksidan $\left(\mathrm{IC}_{50}\right)$ ekstrak etanol buah jeruk pamelo adalah 2882,268 $\mu \mathrm{g} / \mathrm{mL}$ dan nilai $\mathrm{IC}_{50}$ fraksi nheksan adalah $3668,444 \mu \mathrm{g} / \mathrm{mL}$ yang merupakan kategori aktivitas antioksidan lemah.

\section{Ucapan Terima Kasih}

Kami ucapkan terimakasih kepada LP2S Yayasan Wakaf Universitas Muslim Indonesia Makasaar yang telah membiayai penelitian ini

\section{Daftar Pustaka}

Dewi dan Mustika N.H. (2014) 'Bahan pangan, gizi dan kesehatan'. Alfabeta Bandung.

Ervina, SL, Lely ,SL, dan Julia, R. (2013) 'Pelembab Kulit Alami dari Sari Buah Jeruk Bali (Citrus maxima (Burm.) Osbeck)', Journal of Pharmaceutics and Pharmacology, vol. 2, pp 104-111.

Hernanidan\& Raharjo, M. (2005) 'Tanaman Berkhasiat Antioksidan', Cetakan I, Penebar Swadaya, Jakarta.

Junaidi, I. (2011), Ensiklopedia Jus Sayur dan Buah, Penerbit Bhuana Ilmu Populer, Jakarta, Hal 74-75.

Mikhael, GC, dan Soegihardjo. (2013) 'Uji Aktivitas Antioksidan Menggunakan Radikal Bebas 1,1-Difenil-2Pikrylhydrazyl dan Penetapan Kandungan fenolik Total Fraksi Etil Asetat Ekstrak Etanol Buah Anggur Bali (Vitis vinifera L.)I', Jurnal Farmasi Sains dan Komunitas, 
ISSN : 1693-5683, vol. 10 No.2, pp 109120.

Navitri, A.D.,dan Monica, M. (2012) 'Uji Aktivitas Antiradikal Bebas Estrak Buah Jeruk Bal (Citrus Maxima Burm. Fz) Dengan Metode DPPH (1,1DiphenylPikrylhidrazyl)', UNESA Journal of Chemistry Vol. 1, No. 2.

Prakash, A. (2001) 'Antioxidan Activity', medalliom Laboratorium Analytical Progress, vol. 19. pp 2.

Rohdiana, D. (2001) 'Aktivitas Daya Tangkap Radikal Polifenol Dalam Daun Teh', Majalah Jurnal Indonesia, V01.12 (1), pp 53-58.

Sunarni, T. (2005) 'Aktivitas antioksidn penangkp radikal bebas beberapa kecambah dari biji tanaman familia Papilionaceae', Jurnal Farmasi Indonesia, Vol 2 (2), pp 53-56.

Tahir, M. \& Kusuma, A.T.,dan Ekawati. (2018) 'Analysis of Lycopene and Vitamin C Levels of Pomelo Citrus Fruit (Citrus maxima (Burm) Merr) Red and White Varieties From South Sulawesi', Journal of Current Pharmaceutical Sciences, Vol. 2 No.1 September 2018, Hal. 125-130, eISSN :2598-2095, pISSN: 2598-2087.

Tahir, M., dan Melisa. (2017) 'Aktivitas perlindungan sinar uv sari buah jeruk pamelo (citrus maxima (burm.) berdasarkan nilai sun protection factor (SPF)', Poster Ilmiah Seminar Nasional Kefarmasian, STIFA Makassar.

Winarsi, H. (2007) 'Antioksidan Alami dan Radikal bebas' Kanisius, Yogyakarta.

Yanhouy, L, Hong, CO, Nam, MH, and Kim, JH. (2011) 'Antioxidan and Glycation Inhibitory Activities of Gold Kiwifruit', Actinidia chinensis. J. Korean Soc, vol.54, no.3, pp 460-670. 